\title{
DON JUAN MANUEL AND HIS CONNECTION WITH THE ORDER OF PREACHERS ${ }^{1}$
}

\author{
FRANCISCO GARCIA-SERRANO \\ University of California at Berkeley (U.S.A.)
}

Don Juan Manuel (1282-1348) is well known as one of the foremost literary figures of medieval Spain. His endeavors were not, however, confined to literature; he was a multifaceted individual. From the age of twelve he had participated in the frontier war against the Moors and he remained a noble knight throughout his life, proud of his status and skills. King Alfonso XI granted him the prestigious position of adelantado of the frontier and kingdom of Murcia as a reward for his services in Castile's war against the Muslims. As a conscientious religious person, Don Juan Manuel, in fighting the Muslims, sought the best way a nobleman like himself could serve God, gain salvation, and maintain the honor of his social estate. ${ }^{2}$

Don Juan Manuel also played a crucial political role as regent and royal tutor in the crisis during and after the minorities of Kings Fernando IV and Alfonso XI in the early fourteenth century. His political activity, however, led him to dissatisfaction at the end.

In addition to his political ambitions, Don Juan Manuel demonstrated concrete interest in two issues; namely, the hierarchical organization of society and the salvation of the soul. Both were also a substantial part of the church's agenda to which the Dominican Order greatly contributed. In

1 Este trabajo se presentó parcialmente en la reunión de la Society for Spanish and Portuguese Historical Studies en San Antonio, Texas (EE.UU.), 25-28 de Marzo de 1993.

2 «E vos, señor conde Lucanor, pues sabedes que la vuestra caça y la vuestra onra et todo vuestro bien paral cuerpo y paral alma es que fagades seruiçio a Dios, y sabedes que en cosa del mundo, segun el vuestro estado que vos tenedes, no le podedes tanto seruir commo en aver guerra con los moros por ençalçar la sancta y verdadera fe católica, aconsejo vos que luego que podades estar seguro de las otras partes, que ayades guerra con los moros». (Conde Lucanor, example XXXIII). All the quotes from Don Juan Manuel's works are extracted from his Obras completas, José Manuel BleCUA, ed. (Madrid, 1982-1983), except Libros de los Estados from R. B. TATE and I. R. MACPHERSON, ed. (Oxford, England, 1974). 
fact, to the advantage of Don Juan, the Preachers were extremely useful in maintaining the social status quo and in promising salvation for those nobles who supported them. The usefulness of the friars is demonstrated by the fact that in all of his works Don Juan showed not only a commitment toward his own noble estate but also a solid connection with Dominican teaching. .

There was a constant concern in Don Juan's books to make his ideas comprehensible. In the Libro de los estados he pursued that a didactic approach in which the articulation of questions and answers containing examples, was the best form to make concepts more obvious to his readers. ${ }^{3}$ The method of using examples with a didactic purpose, exempla, was indeed the most widely used by the Dominicans. Étienne de Bourbon, for instance, a thirteenth-century French Dominican, compiled influential sermons in Latin which contained numerous exemplary anecdotes of great value for preachers. ${ }^{4}$

Since most people in Castile no longer understood Latin during his time, Don Juan wrote in Castilian to make his work understandable to all. ${ }^{5}$ He used evangelical and didactic fictions known in Castile as fabliellas to inform and educate the nobility as well as the common people regarding social and religious issues. In fact, teaching members of the lower social orders, the third estate, was a powerful weapon for the elite aimed at justifying the inequalities of society and at proselytizing among those who dissented from the status quo of the moment. ${ }^{6}$

3 «Et porque los omnes non pueden tan bien [entender] las cosas por otra manera commo por algunas semejanças, conpus este libro en manera de preguntas et respuestas que fazían entre sí, un rrey et un infante su fijo, et un cavallero que crió al infante et un philósofo. (Libro de los Estedos, II).

${ }^{4}$ Étienne de Bourbon called these exemplary stories similitudines, or similarities. He used them extensively in his Anecdotes bistoriques, legendes et apologues..., ed. $\mathbf{\Lambda}$. LECOY DE LA MARCHE (Paris, 1877), 4: «... in humanis cordibus maxime valent exempla, que maxime erudiunt simplicium hominum ruditatem, et faciliorem et longiorem ingerunt et imprimunt in memoria tenacitatem; ideo summa Dei sapiencia, Christus Jhesus, primo docuit factis quam verbis, et subtilitatem predicacionis et doctrine grossam quasi corpoream et visibilem reddidit, munies et vestiens eam diversis similitudinibus, parabolis, miraculis et exemplis, ut ejus doctrina cicius caperetur, facilius cognosceretur, forcius in memoria retinetur et efficacius opere adimpleretur . See also R. B. TATE and I. R. MACPHERSON, Libro de los Estados, XVII.

3 «Pero Dios sabe que lo fizo [el Conde Lucanor] por entençion que se aprouechassen de lo que el diria las gentes que no fuessen muy letrados nin muy sabidores. Et por ende fizo todos sus libros en romançe, e esto es sennal cierto que lo fizo para los legos et de non muy grand saber commo lo el esw (Conde Lucanor, First prologue).

${ }^{6}$ For the connection between Don Juan Manuel's literature and Dominican thought see María Cecilia Ruiz's Literatura y política: el Libro de los estados y el Libro de las armas de don Juan Manuel, Potomac, 1987, pp. 21-25. 
Don Juan Manuel's works provide us with an excellent opportunity to become familiar with the stories most widely used by the Dominicans in their sermons. Even though the friars did not write in Castilian, it is certain however, that they preached in vernacular languages to make themselves understood and to make the desired impression on their listeners. The exempla of the sermons needed to be presented in the most suitable language of late medieval Castile, which was Castilian, not Latin. ${ }^{7}$ Many sermons included anecdotes that became popular and were transmitted orally from generation to generation, constituting the basis of traditional Castilian tales.

In addition to be exposed to this oral tradition, Don Juan Manuel read Latin and therefore had access to a wide variety of Latin sources. On many occasions he followed Dominican preachers, such as the above mentioned Etienne de Bourbon, not only in method but also in content. The traditional exempla used by Dominican friars to illustrate complex theological concepts appeared regularly in Don Juan Manuel's literature. For instance, several exemplary stories in his literary production are genuinely Dominican, such as the ones about Saint Dominic (example XIV), the Franciscans of Paris (example XXXI), and the fake beguine (example XLII), all of them contained in Conde Lucanor. ${ }^{8}$

The Dominicans found in Don Juan Manuel an excellent communicator and encouraged him to write in Castilian to spread their religious principles. For example, Don Juan's Libro de las armas was written under a request by a friar, Don Juan Alfonso. ${ }^{9}$ Likewise, the Dominican hand is noticeable at the end of Libro de los estados where there is an entire section dedicated to emphasizing the excellences of the friars preacher. ${ }^{10}$ In this

7 Francisco Rico supports this same theory in Predicacion y Literatura en la España Medieval, Cádiz, 1977, p. 8: «Por otra parte, hasta los manuscritos del siglo XV confirman que solían escribirse en latín guiones o textos que luego se pronunciaban en romance. También ocurre lo contrario: cuando se escribía un sermón predicado antes en vulgar, la regla era ponerlo en latín .

8 María Rosa LIDA, Tres notas sobre don Juan Manuel, «Estudios de Literatura Española y comparadax (Buenos Aires, 1966), p. 96. Other authors such as Hermann KNUST, El libro de los enxiemplos del Conde Lucanor et de Patronio, Leipzig, 1900, considered that examples IV, VI, $\mathrm{XI}, \mathrm{XVIII}, \mathrm{XXXVI}, \mathrm{XIV}$, and XLIX are Dominican as well.

9 Giménez Soler, Don Juan Manuel. Biografía y estudio crítico, Zaragoza, 1932, pp. 677 690, includes the entire Libro de las armas, which starts in this way: «Frey Iohan Alfonso: yo don Iohan paré mientes al ruego et afincamiento que me fezistes, que vos diesse por scripto...» We do not know much about Juan Alfonso except for he was a Dominican friar.

10 The importance of the chapter on the Dominicans made nineteenth-century scholars mistakenly think that it was a book by itself. See, for example, Pascual de GAYANGOS, Libro de los Frailes Predicadores, Escritores en prosa anteriores al siglo XV, Madrid, 1860, pp. 364-367. 
same book the character of Julio also presents the key qualities of a preacher missionizing in a distant land. ${ }^{11}$

Finally, another Dominican feature adopted by Don Juan consisted of asserting the Thomist importance of reason to gain faith. In order to have faith, it was first necessary to understand the superiority of the orthodox Catholic religion. This approach carried a certain degree of tolerance in converting infidels since it was emphasized that none should be forced to embrace Christianity; only reason and faith should lead them to do so. ${ }^{12}$ In like manner, Don Juan Manuel resolved to show by means of reason how Catholic religion was superior to all others. He was convinced that, despite the freedom of choice of the individual, Catholicism would be inevitably chosen due to its obvious superiority. ${ }^{13}$

On many occasions well-prepared Dominican preachers were involved in religious debates against infidels to publicly demonstrate the supposed superiority of Christianity. Although taking part in these debates made Christians more knowledgeable of their own faith, there was also a potential danger of exposing the weakness of Catholicism. Heretics, especially Waldensians and Jews, who were well read, could easily refute the arguments of uneducated Christians. Aware of this fact, the Dominicans Saint Thomas Aquinas in his Summa theologica (II, I, quaest. 10, art. 7) and Bernard Gui in his Practica inquisitionis bereticae pravitatis, a manual for inquisitors, warned about the dangers of public debates. Don Juan Manuel also reflected the same concerns in his books and advised his readers avoidance of open religious discussions with nonbelievers. ${ }^{14}$

1 Angel Benito y Duran, El Infante Don Juan Manuel y la Orden de Predicadores, Ciudad Real, 1950, p. 24.

12 „Ca Jhesu Christo nunca mandó que matasen nin apremiasen a ninguno por que tomasen la su ley, ca Él non quiere serviçio forçado sinon el que faze de buen talante et de grado.» (Libro de los Estados, book 1, chapter 30).

13 -Et porque esta ley avemos los christianos, tengo que pues vós non queres crer sinon lo que alcança vuestro entendimiento por rrazón que pues tan grant rrazón ha nuestra ley et ninguna otra non ha, tengo que si vós de rrazón queredes usar, que non podedes nin devedes escusar e tomar nuestra ley de los christianos.» (Libro de los Estados, book 2, chapter 41). «Et commo quier que todo se puede provar por rrazón et fío por Dios que lo mostrare yo en este libro...* (Libro de los Estados, book 2, chapter 4). «Et que provándose por rrazón non se pierda el mereçimiento si la rrazón del omne la alcança por entendimiento. Et esto es porque en la nuestra ley ay dos cosas: la una que es la raíz et el fundamento de la nuestra ley et de la nuestra salvación [ ] et éstas se acançan por rrazón; et la otra es otras cosas que fueron después et non se acançan por rrazón natural, et devémoslas crer por fe.» (Libro de los Estados, book 2, chapter 6).

14 María Rosa LIDA, Tres notas, pp. 100-101, «...era un hecho manifiesto la superioridad del conocimineto de las Escrituras entre herejes y judios». Bernard GuI, Practica inquisitionis bereticae pravitatis, ed. C. DounIs, Paris, 1886, p. 236. The danger of questioning 
The connection between Don Juan Manuel and the Dominicans was not just limited to spiritual and intellectual levels. They self-consciously shared mutual worldly interests as well. In fact, the material advantages that the preachers obtained from Don Juan could only be matched by those they got from the royal family. Possibly Don Juan Manuel tried to gain support over the king from such an influential religious order; by the fourteenth century the Dominicans were far from being a small group of friars begging and struggling to survive. On the contrary, they were highly influential mediators who played a decisive role in internal and external political affairs.

For example, on August 26, 1302, Don Juan Manuel entrusted Friar Gil de Giscón with relevant negotiations regarding his truce with King Jaume II of Aragón. ${ }^{15}$ Don Juan Manuel generally tried to remain on good terms with the Aragonese kings, as a way of securing support in his struggle against the Castilian monarchy. In addition, in 1313, Don Juan married the Infanta Constanza of Aragón, daughter of Jaume II, to seal their alliance. The Preachers also played a part in settling the terms for this marriage. Seven years prior to the ceremony, when Constanza was still a minor, there had been amicable negotiations in which the Prior of the Dominicans of Toledo was engaged to plead on Don Juan's behalf. ${ }^{16}$ Yet another Dominican and personal friend of Don Juan Manuel, Friar Ramón Masquefa, became Prior of the convent of Peñafiel and was continuously entrusted with political missions by the Castilian noble, especially those dealing with King Pedro IV of Aragón. ${ }^{17}$

Don Juan Manuel shrewdly entrusted the Dominicans with his negotiations with the Aragonese monarchs since the Preachers were also highly respected in the Crown of Aragón. King Jaume II sent Dominican preachers in return as emissaries to Don Juan Manuel, as shown in two documents of August 10,1312, which states that the Castilian noble had received Friar Pedro Marsil and Friar Arnalt Amill, both envoys of Jaume

Catholicism was reflected in the debates of Barcelona in 1263 between Christians and Jews. See, for instance, Robert Chazan, Barcelona and Beyond; the Disputation of 1263 and Its Aftermath, Berkeley and Los Angeles, 1992.

is Giménez SOlER, Document XXXVIII.

16 Giménez SOler, document. CXXXVI (January, 1306): «Si oviere ardit que vaya a don Johan vaya ell e digale de part suya que especialmente despues que don Johan le ovo enviado el prior de los predicadores de Tholedo Don Bernat de Sarrian e Cathalin en rason del matrimonio tractado entre su filla la infanta donna Constança e el dito Don Johan aviendo el Rey darago talent de ayuntar...»

17 GIMénez SOlER, documents CCCCV (November-December, 1325), DXXXIII (2 March, 1336), DXXXV (17 March, 1336) and DLXXVII (3 September, 1345). 
II. ${ }^{18}$ Likewise King Pedro IV of Aragón continued the trend of entrusting Dominicans as political intermediaries. ${ }^{19}$

It is clear, then, that the political and familial negotiations between Don Juan Manuel and the Aragonese royal family were repeatedly channeled by way of Dominican friars. In addition, the available documents convincingly show that the Preachers were regarded as very able mediators in the disputes of the elites.

Besides intellectual association and political confidence, the most obvious proof of Don Juan's commitment to the Dominicans was the foundation of the convent of San Juan and San Pablo in his village of Peñafiel in 1318. Peñafiel was a small seignorial village in the northern Castilian plateau located strategically between the Duero and Duratón rivers, not far from the city of Valladolid. ${ }^{20}$ In founding the convent, Don Juan Manuel demonstrated his gratitude for former services and secured Dominican loyalty for the future. The original charter of donation of November 6 , 1320 , is very explicit in showing the privileged status that the Dominicans were acquiring in Castile compared to other religious orders, including the Franciscans of Peñafiel. ${ }^{21}$ The Dominicans received a generous donation that not only contained the palace of Don Juan, but also produced an estimated annual income of about 10,000 maravedís. ${ }^{22}$ The convent conti-

18 Giménez SOLER, documents CCXLII and CCXLIII.

19 Giménez SOLER, 111 and document DXIVII (19 March, 1339). Fray Ramón Guillen was the mediator between don Juan Manuel and Pedro IV. The friar informed the Aragonese king about Castile's political events.

${ }^{20}$ See Julio Valdeon BarUQue, Don Juan Mansel y Peñafiel, «Don Juan Manuel VII Centenario», Murcia, 1982, pp. 385-395.

21 According to S. MOReta Velayos, Rentas monásticas en Castilla. Problemas de método, Salamanca, 1974, p. 105, most Benedictine convents received a martiniega well below 4,000 mrs; for example the monastery of San Pedro of Cardeña received only $618 \mathrm{mrs}$. Don Juan Manuel donated 1,500 mrs to the Franciscans of Peñafiel but far from being a voluntary donation it was a compensation for entering the Franciscan monastery in search of some men guilty of murder: «... que les queriendo faser emienda e satisfaccio al dicho Monesterio por [ ] fise sacar del dicho Monesterio omnes que se avien y acogido por raçon de un omne que mataron en Pennafiel.» Giménez Soler, document DLXXV (7 April, 1345).

22 In addition to the palace of Don Juan Manuel, the Dominicans received new houses, with a chapel and courtyard, and another house called Reina in the nearby place of Botijas. They also received two gardens, Noria and San Pelayo. They were given ownership of mills on the Duratón and Duero rivers and fishing privileges in the Duero river. They also got a pine grove in Huelga Cerezo. Other privileges included an annual donation of 5,000 maravedis from the martiniega tax, all gate tolls (portazgo) which yielded 1,500 maravedis annualy, rights of the prestamería tax, and another direct tax over the people of Peñafiel (guarda). See Elida Garcin Garcin, San Juan y San Pablo de Periafiel. Economía y saciedad de un convento dominico castellano (1318-1512), Salamanca, 1986: Appendix 2 and 12. For an 
nued to enjoy Don Juan's charity until the last moments of his life. In his will he remembered the Dominicans and not only expressed his desires to be interred at the convent of Peñafiel but also bequeathed his entire literary production to the friars. ${ }^{23}$

The frequency of donations by the upper nobility and the royal family gradually led the Dominicans away from their modest beginnings of the early thirteenth century. The friars, in turn, recruited members of the aristocracy to become part of their ranks. Although only one hundred years had passed between the foundation of the first convents in Castile and the foundation of the convent of Peñafiel, there was a clear evolution in the Dominican outlook. The friars preacher, no longer the ascetic men of scarce resources that at first scattered through medieval Europe, could better serve the interests of the nobility. This explains in part the fact that the Dominicans, despite substantially neglecting their original ideal of material poverty, were praised by a powerful noble like Don Juan Manuel. Plainly, by the fourteenth century they had truly become an order of noble status which controlled great power and wealth.

Consequently, the Dominicans had to change their original premises to such an extent that the urban setting so necessary for the preaching of the early friars now yielded to a more traditional and secluded way of religion, similar to that of the pre-mendicant Benedictine monks. The convent founded by Don Juan Manuel illustrates this fact. In effect, Peñafiel was just a small village, very rural, with its only distinction being that of hosting the palace of Don Juan Manuel. The contact between friars and urban inhabitants was meager in Peñafiel since the bourgeoisie and prosperous merchants who crowded the cities were almost nonexistent there. ${ }^{24}$

explanation of the value of Castilian currency see Peter SPUPford, Handbook of Medieval Exchange, London, 1986, pp. 155-161. As an example of the cost of living in the Castile of Juan Manuel the prices of some major items may help; a horse was valued at between 2,000 and 5,000 maravedis, a hawk cost 750, and a house between 7,000 and 12,000. $\Lambda$ pound of mutton or pork was 7 to 8 dineros ( 10 dineros $=1$ maravedi), beef 4 to 6 dineros, lamb 3 to 4 dineros. Salt pork 12 to 14 dineros, a pound of cheese was just over 3 dineros (GIMÉNEZ SOLER, pp. 698, 662-63).

${ }^{23}$ "Otrossi acomiendo mi cuerpo que sea enterrado enel monesterio delos frayres Predicadores que yo fiz en Pennafiel, enel $\mathrm{mj}$ alcáçar en la eglesia nueva ante el altar mayor» (GIMÉNEZ SOLER, p 695). «Et yo (Doña Juana) viendo la santa entencion de Don Johan mi padre que amo todos Religiosos especialmente la Orden de los Frayles Predicadores en la qual Orden en el Monesterio de Sant Johan de la mi villa de Pennafiel escogio su sepultura do jase enterrar en el abito de los dichos freyres a los quales freyres e monesterio dexo rentas ciertas...» [GIMénez SOLER, document DXC (1376), p. 653].

24 The ordinances of Peñafiel are clearly described the comprehensive rural character of the village. See «Ordenanzas dadas a la Villa de Peñafiel por Don Juan, hijo del infante Don Manuel » included in Giménez SOLER, pp. 655-671. 
Preaching, the Dominicans' main activity, would have been hard to exercise in a village which could only offer a limited audience. Furthermore, Peñafiel was a convent of noble origin established to serve the interests of its founder and, accordingly, the Dominicans concentrated on large scale politics instead of preaching.

These radical changes in the Dominican institution are comprehensible in a broader historical context. It is important to keep in mind that the precarious economic conditions that the crisis of the fourteenth century spread across Western Europe progressively made poverty a social plague. Poverty was beginning to be regarded as a social evil rather than as an apostolic virtue; and, as a consequence, the social utility of the mendicant friars was questioned in so far as they lived on the detriment of those who truly were needy. ${ }^{25}$ Social norms were also blurred by the corrupt behavior of both laity and clergy. The claustra, a very lenient way of being religious, was the model followed by most members of religious orders in Castile. Due to this decaying situation, the Dominican masters were forced to initiate a reform in order to reinstate both discipline and the teachings of Saint Dominic. ${ }^{26}$

During this time, the Dominicans were generally closer to the aristocracy, as in Peñafiel, and they were also willing to accept donations that greatly exceeded the restrictive norms of original Dominican poverty. For instance, far from being committed to mendicancy, the convent of Peñafiel accepted jewels and fine garments from Don Juan, and used them openly at weddings and other commemorative services. The material wealth and the questionable behavior of the friars did attrack attention to the point that Don Juan Manuel himself was forced to warn them, threatening to cease giving them more material support. Don Juan's direct reference to donations suggests the high value that the friars attributed to worldly possessions. ${ }^{27}$

Meanwhile, the general social discontent of the fourteenth century generated a clash of interests between the members of the lower estates of

${ }^{25}$ See Michel Molust, The Poor in the Middle Ages, New Haven, 1986, p. 127. On the economic crisis affecting towns in the late fourteenth and fifteenth centuries, see P.B. Hibbert, The Economic Policies of Touns, «The Cambridge Economic History of Europe», III, Cambridge, England, 1963, pp. 157-229, and also J. HuIzINGA's classic, The Waning of the Middle Ages, New York, 1954, pp. 153, 179.

26 V. Beltran De Heredia, Historia de la reforma de la Provincia de España (14501550), Rome, 1939, and Los ńltimos restos de la claustra en Salamanca, «Archivum Fratrum Praedicatorum», XVII (1947), pp. 208-220.

27 AHN, Clero, 3,345/1, 16 r.v. (cf José Luis Martin, Don Juan Manuel, fundador del convento de San Juan y San Pablo de Peñafiel, «Don Juan Manuel, VII Centenario», Murcia, 1982, pp. 177-185). 
society and the aristocracy. In fact, members of the nobility, seeing their rents diminishing, resolutely expressed their power over peasants and city dwellers alike. ${ }^{28}$ Don Juan Manuel was no exception, firmly sustaining his interests against the demands of the cities under his control. But burghers and peasants did not remain passive and demanded justice from the king. As a consequence, in an environment of economic crisis, the social discourse changed and many opposed the "true poor" to the mendicants against whom popular disapproval was rising. Under these conditions it made sense that the Dominicans should seek the protection of the most powerful nobles; after all, both pursued the same interests. Equally so, the populace began to see the friars as distant members of the upper levels of society.

In these times of change, the idea of poverty and of being poor also needed to be redefined by the elite. In his Libro de los estados, considered a truly Dominican work written by a layman, ${ }^{29}$ Don Juan Manuel cleary rejects poverty as a virtue in itself. In this book Don Juan Manuel takes up the controversy of 1321 between Pope John XXII and the Franciscan Order on the question of poverty. John XXII resolved, following the arguments of Thomas Aquinas, that charity, not poverty, was the basis of the perfect life, thus making indigent people -the theoretic beneficiaries of almsgiving - necessary for society; justifying the social order. ${ }^{30}$ Needless to say, charity could only be exercised by those possessing some kind of wealth.

Similarly, the Libro de los estados also states that Christ was not completely poor and did exercise authority over his followers, although he never desired wealth and tended to be pleased with what he owned. ${ }^{31}$ This double affirmation implies that Christ could not fit into either of the two traditional categories of paupers because he was neither poor nor powerless. ${ }^{32}$

28 Julio Valdeon BaruQue, Las tensiones sociales en Castilla en tiempos de don Juan Manuel, "Juan Manuel Studies», ed. Ian MACPHERsoN, London, 1977, pp. 181-192.

29 María Cecilia RuIz, Literatura y política, 21, affirms: «De hecho el Libro de los estados es en cierto sentido una obra dominica, llevada a cabo por un lego [...] tiene como objetivo inmediato este fin predicador.»

30 TATE and MACPHERSON, p. 302.

31 «Et commo quier que muchos ayan movido quistiones en razón de la pobreza de Jhesu Christo la verdad es esta: que Jhesu Christo non fue del todo pobre. Ca fállase por los Evangelios et por la su vida que dineros ovo, et omnes governava et Judas Escariote su mayordomo era. [...] Mas cred por çierto que nunca ovo nin quiso riqueza tenporal, nin villas nin castillos nin dineros nin pannos nin cavallos nin otras vestias para cavalgar» (Libro de los Estados, book 2, XI)

32 Georges DuBY, The Three Orders; Feudal Society Imagined, Chicago, 1980, p. 95. As early as the ninth century the term pauper was used not only to distinguish those who lacked wealth but also those who were powerless. Pauper, thus, became an antonym of potente, a powerful person. 
To solve this problem, poverty was conceived of as an attitude and not as an actual economic status. Being naturally poor or being born poor did not secure spiritual perfection because poor people did not have to renounce a material wealth which they never actually held. Being born wealthy and rejecting wealth was, on the other hand, the most certain way to gain salvation.

Don Juan endorsed these beliefs by pointing out that, despite having other options in life, the merit of salvation lay in being voluntarily poor. ${ }^{33}$ In addition, he states that since education and reason were essential to gaining salvation, members of the lower estates were in greater danger of condemnation due to their ignorance. Under these premises, the third estate of society was therefore not only dispossessed of its material well-being on earth but also of the means to salvation, which were monopolized by the aristocracy as well. ${ }^{34}$

This conception of society brings up the question of social inequality during Don Juan Manuel's life. The hierarchical division in the three estates described in Libro de los estados was thought to be the natural order for society because of its divine origin. Altering the structure of society was thus seen as an act against God's will, embodying the danger of sin or heresy. In consequence, one had to achieve perfection within one's social estate. In general, the Dominicans shared with Don Juan Manuel this static vision of the world, to which they contributed with theories of their own.

In this light the merchants, who were included in the third estate described in the book, were viewed as a danger to Christian society. In the thirteenth century friars and merchants, sharing the same urban and social background, pursued much the same interests. By the early fourteenth century, however, things had changed and the merchants were seen as greedy individuals who could compete for the privileges of the nobility and disrupt the divine order of society.

Don Juan Manuel, too, looked down openly upon merchants in his works and took great pains to distinguish them from the nobility. The

33 «bien así es muy grant meresçimiento el que está en el mundo aviendo muy grant poder para fazer lo que quisiere et conplir su voluntad, [dexa de fazer mal] et non lo dexar por mengua de poder nin de riquezas nin por miedo, et dexarlo por non fazer pesar a Dios, et fazer muncho bien, et non tomar deleite, nin sobervia nin loçanía, por el poder que ha. Ca vós sabedes, sennor, que en el evangelio non loa Dios al pobre, mas loa al pobre de voluntad». (Libro de los Estados, book 1, LV)

34 Juan Manuel describes the members of the third estate as follows: «et porque muchos déstos son menguados de entendimiento, que con torpedat podrían caer en grandes yerros non lo entendiendo, por ende son sus estados muy peligrosos para salvamiento de las almas" (Libro de los Estados, book 1, XCIX). 
nobles were ricos bomnes claiming honor and ancestry while the merchants were just bomnes ricos whose lack of honor deprived them of all purpose except that of making a profit. The merchants were also considered to be harmful to the social order since, much to the dismay of Don Juan Manuel, they sought to improve their social status by means of economic leverage. Despite their wealth, however, they still belonged to the estate of the laboratores because they earned they living. ${ }^{35} \mathrm{~A}$ high social status, thus, was not essential to having a prosperous economic status. While one condition could only be inherited through lineage and could not be won through one's own efforts, the other was obtained through economic growth, in such a manner that, regardless of the amount of wealth possessed, the social status of a nobleman always excelled that of a merchant.

In conclusion, the connection between Don Juan Manuel and the Dominicans reflects how the interests of a nobleman were best fostered by a religious order. Reciprocally, the Dominicans, who abandoned their early devotion to apostolic poverty, sought the protection of the upper nobility to secure their existence in times of dire straits. In the political unrest of fourteenth-century Castile, both gained through their alliance. Both represented, however, powers in risk of decline; the peasants' revolts and the well-organized urban councils channeled the social discontent that caused the voices of the members of the lower society to be heard. As a result the urban centers, taking power away from the nobility, gained representation in the parliament (Cortes) of the highly centralized medieval Castile.

\section{RÉSUMÉ}

Cet article tente de démontrer comment les intérêts sociaux de l'Ordre dominicain ont spectaculairement changé pendant la première moitié du quatorzième siècle. Après avoir été un Ordre engagé dans la pauvreté et prêchant avant tout pour le peuple, les Dominicains s'attacheront plus tard à la noblesse et à leur source de pouvoir et de richesse. L'exemple de Don Juan Manuel, un noble puissant, et

35 «Sennor infante, devedes saber que así commo les dizen rricos omnes, [non] les pudieran dezir omnes rricos. Ca rrico omne et omne rico, a do paresçe que es uno, mas [ha] entre ellos muy grant diferençia. Ca en diziendo omne rrico entiéndese qualquier omne que aya riqueza, también ruano commo mercadero, [...] Mas quando dize[n] rrico omne ponen la rriqueza, que es onra, delante, que quiere dezir que es más onrado que las otras gentes, por los cavalleros que a por vasallos e por el pendón que puede traer» (Libro de los Estados, book 1, XCIX). See also Luciana de STÉPANO, La sociedad estamental de la Baja Edad Media española a la luz de la literatura de la época, Caracas, 1966, pp. 143-144 and José Antonio Maravall, La sociedad estamental Castellana y la obra de don Juan Manuel, Estudios de bistoria del pensamiento español, Madrid, 1983, I, pp. 466-467. 
ses attaches avec les Dominicains aide à illustrer le fait. Les Prédicateurs fournissent à Don Juan les sources intellectuelles, les conseils politiques, la guidance religieuse qui l'aideront à maintenir son statut social. En retour, les moines jouirent de splendides donations et de la haute estime de Don Juan Manuel. L'engagement de Don Juan envers l'Ordre des Prêcheurs n'est pas seulement visible dans la fondation d'un couvent dominicain dans son village de Peñafiel mais apparaît aussi dans ses écrits. L'influence dominicaine fait souvent jour dans les histoires et les exemples employés par Don Juan. La vision que les moines Prédicateurs possédaient du monde l'induisent à concevoir la société comme un ordre traditionnel divisé en trois états et dominé par les nobles et le clergé. Toutefois cette idée de la société était difficile à imposer car le quatorzième siècle était un siècle de défit et de bouleversement pour ceux qui traditionnellement dominaient la société. En conséquence, les Dominicains et Don Juan Manuel se considéraient mutuellement comme des alliés dans leurs intérêts réciproques et s'aidaient à maintenir la société dans un statu quo.

\section{SUMMARY}

This paper intends to show how the social interests of the Dominican Order changed dramatically during the first half of the fourteenth century. From being an Order committed to poverty and preaching the masses at first, the Dominicans became later attached to the nobility and its sources of power and wealth. The example of Don Juan Manuel, a powerful noble, and his connection with the Dominicans helps to illustrate this fact. The Preachers provided Don Juan with intellectual sources, political advise, religious guidance, and helped him to maintain his social status. The friars in turn enjoyed munificent donations and high esteem from Don Juan Manuel. Don Juan's commitment to the Order of Preachers is not only seen in his founding of a Dominican convent in his village of Peñafiel but also in his writings. The Dominican influence is often found in the stories and examles used by Don Juan. The friars' vision of the world induced him to conceive society as a traditional order divided into three estates and dominated by nobles and clergymen. However, this idea of society was hard to impose because the fourteenth century was a time of upheaval and of challenge for those who traditionally ruled society. Consequently, the Dominicans and Don Juan Manuel saw in each other an allied to foster their reciprocal interests and to keep the traditional status quo of society. 